\title{
Panorama of the sustainable development civilization ${ }^{\star}$
}

\author{
Panorama cywilizacji zrównoważonego rozwoju
}

\author{
Antoni Skowroński \\ Institute of Ecology and Bioethics, Cardinal Stefan Wyszyński University in Warsaw, Poland \\ ORCID: https://orcid.org/0000-0002-9275-5026• antoni.skowronski@gmail.com
}

\begin{abstract}
The article is about the conception of sustainable development settled in the context of cultural and civilization changes. It can be taken as an alternative to further civilization development and a new panorama, opening up perspectives for the further sustainable development of civilization. The conception is a global strategy of development. It relies on the including of the natural environment into the social and economic development of a region, country or, from a global perspective, of the whole world. It assumes a long-lasting improvement of the quality of life of the present and future generations which is integrally associated with environmental improvement. It also shows the necessity of the spiritual growth and changes of the material aims of the development into immaterial ones. In all these aims and assumptions, there are a lot of practical and mental problems in the sphere of sustainable development which retard and even make it impossible to put these conceptions effectively into life.
\end{abstract}

Keywords: sustainable development, civilization, life quality, environmental crisis

Streszczenie: Artykuł dotyczy koncepcji zrównoważonego rozwoju w kontekście przemian kulturowych i cywilizacyjnych. Można być ona traktowana jako alternatywa dla dalszego rozwoju cywilizacyjnego i nowej panoramy, otwierającej perspektywy dalszego zrównoważonego rozwoju cywilizacji. Koncepcja ta jest globalną strategią rozwoju. Polega na włączeniu środowiska naturalnego w rozwój społeczno-gospodarczy regionu, kraju lub w ujęciu globalnym nawet całego świata. Zakłada ona trwałą poprawę jakości życia obecnych i przyszłych pokoleń, co jest nierozerwalnie związane z poprawą stanu środowiska. Wskazuje także na konieczność duchowego wzrostu i przemiany materialnych celów rozwoju na cele niematerialne. We wszystkich tych celach i założeniach istnieje wiele praktycznych i psychologicznych wyzwań w związku z wdrażaniem koncepcji zrównoważonego rozwoju. Wyzwania te opóźniają, a nawet uniemożliwiają skuteczną implementację tej koncepcji.

Słowa kluczowe: zrównoważony rozwój, cywilizacja, jakość życia, kryzys środowiskowy

\section{Introduction}

The prehistory of sustainable development is linked to German forestry. This concept was introduced by Hans Carl von Carlowitz and was associated with forest management. Sustainable forest management was to rely on cutting down only as many trees as can grow in their place so that the forest would never be destroyed. In the middle of the 20th century, this concept was revived, but it was extended beyond the sphere of forestry and brought to the global ecological system. In the last quarter of the 20th century, the concept of sustainable development has become very popular. Ahead of the new century, it

\footnotetext{
* This article was originally published in Polish as Skowroński, Antoni. 2006. „Panorama cywilizacji zrównoważonego rozwoju." Studia Ecologiae et Bioethicae 4: 243-257. The translation of the article into English was financed by the Ministry of Science and Higher Education of the Republic of Poland as part of the activities promoting science - Decision No. 676/P-DUN/2019 of 2 April 2019. Translation made by GROY Translations.
} 
is still a popular alternative to the development of the civilizational world.

Development of civilization is both our blessing and a curse. It is a blessing, because the development of science and technology improves and enhances our life, changes its quality, we have a chance to conquer and discover the world, we can effectively heal people, broaden our horizons and so on and so forth. But it is also our curse as it leads to a decrease in the quality of life, causes threats to mental and physical health, catastrophes, disasters, destruction of natural resources, and other adverse civilizational effects at a global level.

The model of socio-economic development, based on continuous growth of consumption of goods and services, fossil fuels, development of the automotive industry, mass production of disposable products and accumulation of waste, destroys ecosystems on which we depend in our biological existence. Such economic growth and development of civilization cannot last forever, because it will not satisfy the future needs of the growing world population ${ }^{1}$. The search is, therefore, focused on the development of a new, more sustainable model for the development of our civilization.

The aforementioned concept of sustainable development can be used as an alternative for the world. This idea, understood as a global strategy of development, aims to improve the quality of life and increase the prosperity of people, through socio-economic development, in conditions of finite and limited natural resources. It is complemented by a necessary co-responsibility and solidarity between the present and future generations, and a new form of ethics, sometimes called environmental ethics. In these general assumptions and objectives, sustainable development faces many practical and mental problems that

\footnotetext{
${ }^{1}$ History teaches us that the civilizations we have known so far, after reaching the peak of their civilizational lifespan, have lost their developmental momentum and leaned toward collapse. This is stated in (Capra 1987), whereas selected examples are described in (Kozłowski 2005, 27-34).
}

retard or even prevent the effective implementation of this concept.

\section{Civilization and its development}

The condition for exceeding the natural limitations and barriers to the development of the humankind was the emergence of human mental abilities. The ability of abstract thinking introduced great changes in the history and created a new order, which with time stood in opposition to nature. This new order is the culture that belongs exclusively to the humankind and is the sum of experience and collective knowledge accumulated and recorded in social memory (Kaczorowski 2004b, 716). On its basis, specific principles, models and patterns of a general perception of the world were formed. It remembers all the cognitive knowledge and records the practical, ethical, political or social norms, which are components of the further development of human civilization (Zięba 1995, 24).

The existence of culture has made it possible for humans to "break out" of the constraints of biological evolution and to transmit a lot of information through non-genetic means (Kunicki-Goldfinger 1993, 64). Thus, today, humans inherit traits common to all living beings (biochemical identity) and what is the result of human activity (culture) (Cyrzan 1999, 54), so it can be said that "human lives in culture while bearing nature inside" (Morin i Zimand 1977, 36). It is the basic determinant included in the development of civilization.

Culture has become a specific property of the humankind and has caused further intellectualization and humanization of nature (Adamski 1996). And over time, it has led to the emergence of a new environment for living and developing humankind (Łapiński 1999, 165-166; Hull 1992, 3132). Systematic, conscious and purposeful transformation and complementation of nature have led in consequence to the emergence of a new living space, which is commonly referred to as a "socio-natural environment". This term should be under- 
stood as a totality of conditions and factors in which living beings exist. This environment is a set of conditions necessary and sufficient for the life of the earth to exist and develop, and for the human being to exist and develop as well. For the further development of humankind, many natural elements, as well as artefacts and anthropogenic elements are needed ${ }^{2}$. The constant growth of these anthropogenic elements is a result of the development of science and technology. It is knowledge, technique and technology that are indicators of the mastery of the forces of nature and the use of its resources to satisfy various human needs. That is how the civilization was born.

In the past, the terms "culture" and "civilization" were used interchangeably. Currently, the term "culture" is used to describe spiritual, rather than material, heritage (Kaczorowski 2004b). By "civilization", on the other hand, we mean the level of development of society in a given historical period, which is characterized by a certain level of material culture, the degree of mastery of the natural environment, and the accumulation of social institutions (Wikipedia 2006). Civilization is the highest level of organisation of societies which individuals identify themselves with. An important indicator of the level of material culture is the ability to use and shape nature. Thus, it can be said that nowadays the term "civilization" should be understood as a type of socially, materially and ideologically advanced culture, specific to so-called civilized societies (com-

\footnotetext{
2 This environment consists of natural elements (structural elements of the environment): atmosphere, hydrosphere, lithosphere, cosmosphere and biosphere, as well as of artificial elements created by humans - anthroposphere. This term means a human being and their overall, i.e., in the aspect of time and space, work. Antroposphere creates a social environment in which people are born, develop and die. The essential elements of this environment include science, technology, art and religion. Other names used to emphasize only some aspects of this environment are: cultural, technical, civilizational, religious, etc. (Dołęga 2001, 127-142; Dołęga 1999, 15; Bielicki 1969, 85-86).
}

plex), opposed to non-civilized ones (simple) and as a definition of the highest stage of cultural development in the system of human evolution.

Thanks to the scientific and technical civilization, humankind has replaced the direct action of biological mechanisms with a system of social and economic development created by itself. This has led to the emergence of many dangers, and even the prospect of self-destruction of humanity (Piątek $2005,17)$. Sources of ecological threats and the emergence of civilizational barriers should be linked to the uncontrolled human desire to meet new civilizational needs at the expense of fulfilling biological and social needs, at the lowest financial cost. The various systems of civilization known in history died suddenly, precisely as a result of the depletion of resources, or died slowly, as a result of stagnation, which was the result of an inability to learn and, as a consequence, an inability to adapt to changed environmental conditions.

However, I think that regressive, unfavourable changes in civilization can be stopped, provided that we apply a model of development that reconciles ecological laws with the rational and legitimate expectations of people living in a particular place and time. This thesis can also be confirmed by the fact that in economic programmes and strategies, politicians tend to refer more often to the concept of "sustainable development" than to technical or economic progress (Borkowski 2001, 71). This concept assumes the continued existence of nature and civilization and the gradual improvement of the quality of life of current and future generations. Environmental protection is closely linked to the improvement of the quality of life and development. The aim of this action is to maintain environmental parameters that "...make it possible to achieve the current development goals (continuous growth of prosperity, life comfort, consumption, etc.) and at the same time ensure the protection of humans and important ecosystems against biological degradation and extermination" (Hull 1993, 7). In order to 
embark on this path of the development of civilization, humanity must change its current style of development based only on "growth" and adapt its socio-economic system to natural possibilities of the natural environment.

We are convinced that the development of our civilization (Euro-Atlantic civilization) is based on the growth of knowledge, technical innovations and created material needs (Kaczorowski 2004a, 342). These are the main prerogatives of the development. They are in opposition to culture, which, as I mentioned earlier, is identified more with the sphere of spiritual, aesthetic or moral values. Therefore, it is logical and justified to take "sustainable development" as an alternative model for further progress in civilization. This idea consists of and reconciles both material development and cultural progress. By constructing further strategies and plans for global civilization development based on its assumptions, we have a serious chance to eliminate threats that retard and deny further economic, cultural and civilization development.

\section{An alternative to the development of civilization}

The English term sustainable development, functions under different terms in the Polish literature on the subject: zrównoważony rozwój [sustainable development], trwały rozwój [continuous development], rozwój samopodtrzymujqcy sie [self-sustainable development]. It is also often referred to as ekorozwój [eco-development $]^{3}$. The concept of sustainable development has been shaped in the context of the work of the UN international body. Officially, the concept of sustainable development, which had been developed and improved since the Stockholm Conference in 1972 (Paczuski 2000, 32-37; Kozłowski 1998a), was adopted at the "Earth Sum-

${ }^{3}$ The concept of sustainable development has become established in environmental law. Apart from it, there is also the commonly used concept of eco-development. These terms are often used interchangeably. I will also use these terms interchangeably in this article. mit" held on June 1992 in Rio de Janeiro. Two basic documents were adopted: The Rio Declaration - the general philosophy of sustainable development and Agenda 21 - a document outlining the ways, principles and mechanisms for implementing the concept.

The concept of eco-development proposes many new solutions, deviating from the traditionally adopted and implemented assumptions of economic, technical or social development. It aims to reconcile the various orders: ecological, social, economic, technical-technological, cultural and axiological in a harmonious whole. Moreover, it integrates the natural environment into the social and economic development of a region, country or world (Żukowska 1996, 201). Analyzing these assumptions and objectives, one can risk a statement that sustainable development is not an entirely new philosophy of global social and economic order, which industrial countries developed in the late 20th century. It is a concept according to which humans lived in the beginning of our civilization, in harmony and order with nature and other people, and now they are simply rediscovering it (Hutniczak i Jurzak 2006, 84). This re-discovery means, among other things, understanding the differences between "development" and "growth".

The process of directional changes, stretched out over time, in which the objects (systems) move from simple forms or states to increasingly more complex and advanced states, has been called "development" (Kaczorowski 2004c). This development is often confused with "progress" and "growth" in everyday language. The idea of progress is as old as that of civilization, and in common sense, it means an improvement of the previous state of affairs, and thus assumes a change for the better as opposed to regress. In our civilization, there is a paradigm of "scientific and technological progress" that, on the basis of a linear and quantitative model of development, assumes that the increasing number of scientific discoveries and technical inventions leads to an increased and 
improved quantity of goods and, consequently, to an increase in global prosperity (Borkowski 2001, 12). The third term that appears in this context is "growth", which mainly implies quantitative changes, excluding qualitative revaluations.

The idea of sustainable development is to reconcile and combine two contradictory and seemingly antagonistic concepts of "growth" and "development" into one compatible whole. "Growth" aims at the increase of matter, while "development" aims at a fuller, bigger or better state by expanding or realizing certain possibilities (Machowski 2003, 100-101). Bearing this difference in mind, this concept proposes the continuation of the development of civilization together with the social and natural environment. This is the specific novelty and originality of this approach (Michnowski 1994, 145).

In the analyzes of the idea of "sustainable development", care for the present and future generations appears. It is about raising the awareness that other generations will come after us and we cannot live at their expense. We must give up our egoism and species egalitarianism. This truth is written in many expressions of the eco-development. If we assume that "eco-development" and "sustainable development" in the common understanding are the same thing, then we can also define sustainable development as a programme for the restructuring of economic, social and technical links, aimed at protecting nature and human environment for the benefit of present and future generations, and in recognition of the value of nature as such. This includes the long-term use of renewable natural resources, the efficient exploitation of non-renewable energy sources, maintaining the stability of ecological processes and ecosystems, preserving and improving human health, occupational safety and well-being .

${ }^{4}$ This definition was formulated in 1990 by Polish and American scholars and written down in a document: Środowisko a rozwój Polski. Deklaracja ekorozwoju, Białystok 1990. Cit. acc. to (Kozłowski 1997, 154).
Konrad Waloszczyk also understands sustainable development as a concept that is able to provide us with further development and prosperity, but under completely different and opposing conditions to the current concept of prosperity, based on materialistically understood economic growth. This line of development is replaced by the idea of growth balancing the economy with the opportunities and values of the environment and with the concern of ensuring prosperity of all people, local and regional communities and maintaining the development potential for future generations (Waloszczyk 2004, 14). So it is "a concept of prosperity harmonizing economic, ecological and social values" (Waloszczyk 2004, 19). In this spirit, the concept of sustainable development is also included by Franciszek Piontek. He defines it as: “... a lasting improvement in the life of the present and future generations through shaping relevant proportion between the three types of capital: economic $(\mathrm{E})$, human $(\mathrm{H})$ and natural $(\mathrm{N})$ (Hutniczak i Jurzak 2006, 88). A similar definition was accepted at the Johannesburg Earth Summit in 2002, where the desire to put this principle into effect was adopted into the Declaration on Sustainable Development.

\section{Mental and consciousness-based difficulties with sustainable development}

There are real barriers that make it difficult, or even impossible, to put this theory into practice in the world economy and socio-cultural development, the elements that make up civilization. At the above mentioned Earth Summit in Johannesburg, the practice of ten-year implementation of this idea was criticized. It was concluded that without a deep transformation of the consciousness, without a reform of the current system of global economic and environmental management and without a change in the priorities of the global economy, the implementation of sustainable development might fail (Mizak 2004). This fear is deepened by the weak involvement of the governments of the most developed countries in the world, the lack of 
political coordination and the weak, or in fact none at all, financing of this concept. The fundamental problem is the lack of real and genuine political will.

Zdzisław Sadowski sees the need to establish as soon as possible an institutional system that would be able to create, promote and implement a uniform development policy based on the legitimate demands of eco-development (Sadowski $2003,14)$. Another issue is the ineffective policy of equalizing living standards and development opportunities in particular areas of our globe. It must not be forgotten that the need, poverty, lack of property, capital=and knowledge lead to irrational and unsustainable use of natural resources by the poorest countries. Poverty affects the environment, but vice versa, the poor environment increases poverty (Waloszczyk 2004, 17). Progressive globalization, which was seen as an opportunity for sustainable development, quickly turned out to be a kind of "fiction", which began to be treated as a set of actions aimed at consolidating the hegemony of large global corporations and rich countries, including the USA and Europe. While developing the current economic policies aimed at maintaining high levels of consumption without fundamental changes, rich societies seem to either ignore the growing environmental risks or shift these risks to poor countries through legal and even illegal export of pollution and obsolete technologies. There is no general awareness that while economic and political difficulties can be overcome in the lifetime of one generation, the effects of an environmental disaster will last much longer, affecting dozens of future generations.

Another source of difficulties in the process of implementing sustainable development is the system of values dominant in highly developed societies (Fri 2001, 244-245). In this system, the desire to have prevails over the way of "being" (Stacewicz 1998, 112). An important reason for retarding the implementation of sustainable development on a global scale is the objectification of human desires (Kozłowski 1998b, 91). Moreover, socio-economic development and technical progress are far ahead of the intellectual and psychological development of humans (Czyż 2000, 83). These are moral and ethical problems, resulting from the currently dominant pattern of the development of civilization ${ }^{5}$.

\section{Indications significant for sustainable civilization}

The engine that transforms the existing civilization into a civilization of sustainable development should be the change of fundamental attitudes and behaviors of humans in the industrial and technical era, in favor of the attitudes and behaviors of human in the ecologic era. This means that in the time perspective, living standards of the consumer civilization must change (Hronec 2000, 107; Piontek 1999, 120121). Achieving this revaluation is a key issue for the sustainable development of our world. Theoretical and practical actions aimed at promoting such development require a number of coordinated actions of a scientific, forecasting, decision-making, economic, technical, ecological, but also consciousness-based and educational or even ethical nature. In practical terms, this means translating sophisticated theories and political declarations into concrete human behavior in the individual and social dimension.

Many of the difficulties that have arisen during the implementation of sustainable development are linked to the lack of sufficient funding for this process. Therefore, proper financing is an essential condition for the optimal functioning of the eco-development concept at the current implementation level. This can be ensured by introducing appropriate environmental taxes and charges, as well as by reducing expenditure in other sectors of the economy, e.g. arms industry, and shifting the saved funds to implement sustainable development (Rudnicki 2001, 15-16). However, the proper functioning of sustainable development does not depend solely on the

5 The above issues are discussed in more detail in (Skowroński 2004). 
financial resources allocated for this purpose, but on awareness and public acceptance. In this respect, it could be helpful to set up an international organization that would make political and organizational decisions on global environmental risks.

Crucial tasks in the process of building a civilization of sustainable development include, among others: (Michnowski 1992)

- promotion of human, individual and collective information and knowledge,

- connecting the eco-social utility of the work of individuals and organizations with the amount of income obtained as a result of this work,

- mastering the skills of long-term forecasting and rational valuating of work and the effects of other changes in the environment,

- laying out the foundations (also in terms of information) for flexible and ecologically useful management, capable of anticipating any threats,

- mastering the ability to recognize the state of quality of life based on ecological knowledge,

- mastering the ability to control the processes of changes in the natural environment of humans.

The above tasks, together with the assumptions of the ecological era, are the starting point for devising detailed development strategies. Such strategies must also take into account the necessity of greening the economy, combined with environmental protection (Żukowska 1996, 201). At the current stage of the development of civilization, natural environment practically does not exist. There is, on the other hand, natural environment that must be wisely shaped, in line with the eternal laws of nature. If this condition is fulfilled, there is a chance for further development and coexistence of industry, natural environment and humans (Bender 2003, 191192). So far, however, global societies have preferred environmental economization, which is based on economic and technical means of protection. All economic entities wishing to implement sustainable development in their production processes should comply with the following requirements: (Kośmicki 1997, 25)

- reduce the consumption of non-renewable natural resources to zero,

- use renewable resources, however, the net sum of their use and regeneration must not increase,

- control the emission of harmful substances at a level no higher than the absorption capacity of nature,

- reduce the burden on the environment created by substances that are difficult to decompose until they are completely eliminated,

- limit the use of the surface to an ecologically harmless level,

- avoid major risks, the effects of which are linked to irreversible damage to ecosystems and social systems that cannot be estimated,

- preserve maximum species diversity and thus the viability of ecological systems and food chains,

- develop ways of life and consumption that protect the environment,

- properly shape the natural and cultural space of human life.

Also important, from a practical point of view, are all economic activities limiting energy and material consumption of industry and raw materials processing that enable space-saving management and limit the development of communication infrastructure and industrial risks. The assessment of current risks and directions of proposed countermeasures in this area are presented in table below ${ }^{6}$.

Sustainable development also requires the industry to improve output levels and minimize input levels, as well as produce as little waste as possible (Szaniawska i Szaniawski 1995, 51). This is related to the continuous improvement and search for new techniques and technologies harmless to the environment. The coordination of sustainable development objectives with spatial planning is also worth mentioning (Szponar 2003, 245). Spatial planning in the

${ }^{6}$ Stefan Kozłowski provides schematic depiction of the implementation tasks in his article. The table in the paper is based on (Kozłowski 1996, 19-21). 


\section{Proposal for action for sustainable development}

\begin{tabular}{|c|c|c|c|}
\hline No. & Tasks & Assessment of the situation & Task proposals \\
\hline 1. & $\begin{array}{l}\text { Reduction } \\
\text { of energy } \\
\text { consumption }\end{array}$ & $\begin{array}{l}\text { In 1995, as much as } 9300 \text { Mtoe }^{*} \\
\text { from non-renewable resources } \\
\text { were taken, causing climatic, } \\
\text { landscape and social changes }\end{array}$ & $\begin{array}{l}\checkmark \text { stabilization of energy consumption } \\
\text { in the highly industrialized countries, } \\
\checkmark \text { introduction of an energy tax, } \\
\checkmark \text { mastery of new safe energy sources, } \\
\text { e.g. solar energy. }\end{array}$ \\
\hline 2. & $\begin{array}{l}\text { Reduction } \\
\text { of material } \\
\text { consumption }\end{array}$ & $\begin{array}{l}\text { The flow of materials causes } \\
\text { a waste disaster }\end{array}$ & $\begin{array}{l}\checkmark \text { reduction of material input, } \\
\checkmark \text { increase of waste disposal prices, } \\
\checkmark \text { closing the material cycle (recycling). }\end{array}$ \\
\hline 3. & $\begin{array}{l}\text { Economical space- } \\
\text { management }\end{array}$ & $\begin{array}{l}\text { Shrinkage of agricultural land } \\
\text { Progressive devastation } \\
\text { of the landscape }\end{array}$ & $\begin{array}{l}\checkmark \text { protection and reclamation } \\
\text { of agricultural land, } \\
\checkmark \text { exclusion from the use of ecological } \\
\text { compensatory and landscape areas, } \\
\checkmark \text { introduction of tax on building on land, } \\
\checkmark \text { establishment of landscape } \\
\quad \text { restoration fund. }\end{array}$ \\
\hline 4. & $\begin{array}{l}\text { Limiting the } \\
\text { development } \\
\text { of communication } \\
\text { infrastructure }\end{array}$ & $\begin{array}{l}\text { Current trends } \\
\text { in the development } \\
\text { of communication } \\
\text { infrastructure cause } \\
\text { degradation of cities } \\
\text { and landscape }\end{array}$ & $\begin{array}{l}\checkmark \text { adoption of the „zero option” in the } \\
\text { planning of communication networks, } \\
\checkmark \text { introduction of assumptions of the } \\
\text { eco-efficiency of public transport. }\end{array}$ \\
\hline 5. & $\begin{array}{l}\text { Reduction } \\
\text { of industrial risks }\end{array}$ & $\begin{array}{l}\text { Increasing risks associated } \\
\text { with industrial accidents }\end{array}$ & $\begin{array}{l}\checkmark \text { adoption of the following rules: } \\
\checkmark \text { no deterioration of the prosperity } \\
\text { of future generations, } \\
\checkmark \text { no underestimation of risk, } \\
\checkmark \text { no conversion of risks to potential } \\
\quad \text { benefits, } \\
\checkmark \text { introduction of obligatory insurance } \\
\text { against accidents. }\end{array}$ \\
\hline
\end{tabular}

"Mtoe - equivalent of million tons of oil.

spirit of sustainable development is an effective tool that creates a desirable economic, spatial and living system for civilization.

Another necessity is a gradual but fundamental change in the global economic system. The dominant indicator of social and civilizational development at present is the Gross National Product (GNP) indicator, which is based on the rapid consumption of natural resources. It is a measure of the "current monetary value of all final goods and services produced in a given economy over a specified period" (Borys 1999, 35). This is used as a common indicator of the style and standard of living of individual world societies. In the early 1990s, UN agencies proposed a new measure of social development. The proposed social development index (HDI - Humane Development Index) is based on three components: life expectancy at birth, level of education, knowledge and access to 
education of citizens and gross domestic product per capita.

The dissemination of this indicator in global politics and economy could become an adequate verification of the development of civilization. However, this require changes in the current awareness of the world community and its acceptance by the ruling elite and world business.

In order to properly implement the principles of sustainable development, several educational measures should be undertaken immediately and the previously dominant value system should be modified. Environmental education is an important method of effective implementation of sustainable development principles. Environmental education is supposed to change people's way of thinking from the position of "conqueror" to the position of "environmental partner" (Cichy 1996, 6; Kowalak $2000,5)$. It is, therefore, necessary to develop the education process and promote the development of a knowledge-based economy.

The overriding task of environmental education in the broadest term - not only in schools and at universities, but also workplaces, youth and social organizations, churches and religious associations - is to explain and disseminate the concept of eco-development as an alternative lifestyle that provides us and future generations with the right conditions for existence. The young generation will live in a strongly computerized environment - which is also one of the assumptions of eco-development - and, therefore, must learn to think creatively, ask questions and solve problems based on gradually gained knowledge, as well as to logically and independently think and draw conclusions (Nowicki i Ribbe 2001, 179).

The process of balancing the development of civilization assumes a change in the fundamental attitudes and behaviors of people in the industrial and technical era. From the axiological and ethical point of view, the content of eco-development becomes a moral obligation toward other forms of life (nature) and other people liv- ing now and in the future (Hull 1993, 7). Sustainable development requires ethical maturity and a fundamental increase in the intellectual potential of the global community and further appropriate development of science and technology (Michnowski 1995, 35). For the eco-developmental transformation of civilization, it is necessary to "replace the existing (...) forms of growth at the expense of the environment with qualitatively new forms of socio-economic life and development together with the social and natural environment" (Apel Warszawski 1994). This task seems to be the most difficult to accomplish. However, the success of sustainable development and the continuation of our civilization depends on it.

\section{Conclusions}

I suppose that the future of sustainable development will depend on the severity of disasters, catastrophes and environmental threats, including the degree and scale of depletion of natural resources. This will naturally encourage the global community to become more committed to an alternative version of the development of civilization. As I tried to show in this article, such an alternative, already developed and quite well analyzed, is the idea of sustainable development. Taking it as a point of reference, we are offering a new panorama of stable and sustainable civilizational development of all inhabitants of the Earth.

Sustainable development is such an alternative model of existence and development of civilization. Unfortunately, so far this verbalized concept still looks better in theory than in practice. There is a number of barriers to the implementation of sustainable development principles and methods. Among them, mental and awareness-related barriers are very crucial. Therefore, the goodwill of scientists, politicians, strategists and experts of socio-economic development and those in power at various levels, from international organizations, through national governments and economies, to local and regional authorities is needed first. There 
is also a need for continuous intellectual development, which leads to a better understanding of this concept and education of people's awareness and responsibility for the environment of life and further development of civilization.

We owe the progress of civilization to the search for new ways to enrich ourselves and improve our behavior. The wisdom lies in not looking for these solutions at the last minute. We can avoid many crises if we can predict them in time and face them together. Intellectual analysis of the concept of sustainable development is carried out in different directions. It thus opens up a new panorama of the development of civilization for the future. We just have to use this opportunity wisely and responsibly. I believe that despite its shortcomings and criticisms, the concept of "sustainable development" deserves attention as a specific alternative to further development of civilization.

\section{Bibliography}

Adamski, Franciszek. 1996. „Kultura między sacrum a profanum." Forum Philosophicum 1: 91-93.

„Apel Warszawski." 1994. Ekonomia i Środowisko1(4): 164.

Bender, Jan. 2003. Biosfera a cywilizacja. Europa - synonim postępu. Poznań: Wydawnictwo Prodruk.

Bielicki, Tadeusz. 1969. „Antroposfera.” W Maty stownik antropologiczny, red. Tadeusz Bielicki, 85-86. Warszawa: Wydawnictwo Naukowe PWN.

Borkowski, Robert. 2001. Cywilizacja, technika, ekologia. Wybrane problemy rozwoju cywilizacyjnego u progu XXI wieku. Kraków: AGH Uczelniane Wydawnictwo Naukowo Dydaktyczne.

Borys, Tadeusz (red.). 1999. Wskaźniki ekorozwoju. Białystok: Wydawnictwo Ekonomia i Środowisko.

Capra, Fritjof. 1987. Punkt zwrotny. Warszawa: Państwowy Instytut Wydawniczy.

Cichy, Danuta. 1996. „Międzynarodowe i krajowe projekty edukacyjne przygotowaniem do zrównoważonego rozwoju." W Wspótpraca międzynarodowa w edukacji ekologicznej.
Materiaty pokonferencyjne, red. Jan Tulik, 3-8. Krosno: Fundacja Centrum Edukacji Ekologicznej Wsi.

Cyrzan, Honorata. 1999. „Kim jest człowiek? Ekologiczne implikacje nowego spojrzenia na ewolucję (człowieka)." W Ochrona środowiska w filozofii i teologii, red. Józef M. Dołęga, i Jacek W. Czartoszewski, 45-56. Warszawa: Wydawnictwo ATK.

Czyż, M. 2000. „Rozwój zrównoważony a przemiany cywilizacyjne." W Ekologia a transformacje cywitizacyjne na przełomie wieków, red. Stanisław Zięba i Zbigniew Wróblewski, xx-yy. Lublin: Zakład Ekologii Człowieka KUL.

Dołęga, Józef M. 1999. „Problematyka ochrony środowiska społeczno-przyrodniczego w sozologii i ekofilozofii." W Ochrona środowiska w filozofii i teologii, red. Józef M. Dołęga, i Jacek W. Czartoszewski, 10-26. Warszawa: Wydawnictwo ATK.

Dołęga, Józef M. 2001. Koncepcja sozologii systemowej. Warszawa: Wydawnictwo UKSW.

Fri, Robert W. 2001. „Historia naturalna a wiek XXI." W Oblicza Ziemi. Zagrożenia i nadzieje, red. Daniel B. Botkin et al., 240-251. Warszawa: G+J RBA.

Hronec, Ondrej. 2000. „Ekorozwój - jedyna droga w przyszłość." W Miasto i wieś wspólnie na drodze do ekorozwoju, red. Adam Kowalak, 101-112. Krosno: Fundacja Centrum Edukacji Ekologicznej Wsi.

Hull, Zbigniew. 1992. „Filozoficzne podstawy ekorozwoju." Zeszyty Problemowe Postępów Nauk Rolniczych 401: 27-40.

Hull, Zbigniew. 1993. „Dylematy i wymiary ekorozwoju." Postępy Nauk Rolniczych 40(3): 5-14.

Hutniczak, Anna, i Izabela Jurzak. 2006. „Analiza wybranych kwestii dotyczących kapitału ludzkiego w odniesieniu do rozwoju zrównoważonego i trwałego oraz do otaczającej nas rzeczywistości." W Zrównoważony rozwój a ochrona środowiska. Materiaty konferencyjne, red. Beniamin Więzik, 78-89. Bielsko Biała: Wydawnictwo Akademii Techniczno Humanistycznej.

Kaczorowski, Bartłomiej. 2004a. „Cywilizacja.” W Nowa Encyklopedia Powszechna PWN, vol. 2, red. Bartłomiej Kaczorowski et al., 342. Warszawa: Wydawnictwo Naukowe 
PWN.

Kaczorowski, Bartłomiej. 2004b. „Kultura.” W Nowa Encyklopedia Powszechna PWN, vol. 4, red. Bartłomiej Kaczorowski et al., 716. Warszawa: Wydawnictwo Naukowe PWN.

Kaczorowski, Bartłomiej. 2004c. „Rozwój.” W Nowa Encyklopedia Powszechna PWN, vol. 7, red. Bartłomiej Kaczorowski et al., 716. Warszawa: Wydawnictwo Naukowe PWN.

Kośmicki, Eugeniusz. 1997. „Środowiskowe dylematy ekorozwoju a przyszłość polskiego rolnictwa." Ekonomia i Środowisko nr 1(10): 21-33.

Kowalak, Adam. 2000. „Świadomość ekologiczna a realizacja idei zrównoważonego rozwoju." W Miasto i wieś wspólnie na drodze do ekorozwoju, red. Adam Kowalak, 3-11. Krosno: Fundacja Centrum Edukacji Ekologicznej Wsi.

Kozłowski, Stefan. 1996. „Zrównoważony rozwój - wyzwanie przyszłości." Człowiek i Przyroda 5: 19-21.

Kozłowski, Stefan. 1997. W drodze do ekorozwoju. Warszawa: Wydawnictwo Naukowe PWN.

Kozłowski, Stefan. 1998a. Ekologiczne problemy przyszłości świata i Polski. Warszawa: Dom Wydawniczy Elipsa.

Kozłowski, Stefan. 1998b. „Ogólne uwarunkowania ekorozwoju." W Sterowanie ekorozwojem. Teoretyczne aspekty ekorozwoju, t. 1, red. Bazyli Poskrobko, 84-98. Białystok: Wydawnictwo Politechniki Białostockiej.

Kozłowski, Stefan. 2002. Ekorozwój - wyzwanie XXI wieku. Warszawa: Wydawnictwo Naukowe PWN.

Kozłowski, Stefan. 2005. Przyszłość ekorozwoju. Lublin: Wydawnictwo KUL.

Kunicki-Goldfinger, Władysław J. H. 1993. Znikąd donikad. Warszawa: Państwowy Instytut Wydawniczy.

Łapiński, Jacek. 1999. „Pradzieje’ Homo technicus." Studia Philosophiae Christianae 35(2): 162-189.

Machowski, Jacek. 2003. Ochrona środowiska. Prawo $i$ zrównoważony rozwój. Warszawa: Wydawnictwo Akademickie „Żak”.

Michnowski, Lesław. 1992. „Ekorozwój jako forma współżycia." Wieś i Państwo 2: 38-47.

Michnowski, Lesław. 1994. „Ekorozwój - nadzie- ja, konieczność, szansa." Nauka 1: 145-156.

Michnowski, Lesław. 1995. „Megatrendy alternatywne. Ekorozwój albo zagłada ekologiczna." W Ekorozwój. Jego istota i moźliwości wdrożenia. Materiaty pokonferencyjne, 3039. Poznań.

Mizak, Jacek. 2004. „Szczyt w Johanesburgu.” Dostęp: 16.03.2004. http://www.unic.unorg. $\mathrm{pl} /$ johanesburg/.

Morin, Edgar, i Roman Zimand. 1977. Zagubiony paradygmat - natura ludzka. Warszawa: Państwowy Instytut Wydawniczy.

Nowicki, Maciej, i Lutz Ribbe. 2001. Problemy ekorozwoju Polski. Warszawa: Agencja Reklamowo-Wydawnicza A. Grzegorczyk.

Paczuski, Ryszard. 2000. Prawo ochrony środowiska. (Stan prawny na dzień 30 września 2000). Bydgoszcz: Oficyna Wydawnicza Branta.

Piątek, Zdzisława. 2005. „Człowiek jako podmiot zrównoważonego rozwoju: kontrowersje filozoficzno-społeczne." W Zrównoważony rozwój. Od utopii do praw człowieka, red. Andrzej Papuziński, 14-30. Bydgoszcz: Oficyna Wydawnicza Branta.

Piontek, Barbara. 1999. „Jakość życia i sposoby jej mierzenia w strategii wzrostu gospodarczego i zrównoważonego rozwoju." Problemy Ekologii 6(3): 219-225.

Rudnicki, Maciej. 2001. „Instrumenty ekorozwoju. Prawne, ekonomiczne, finansowe." EKO Finanse 71(4): 13-21.

Sadowski, Zdzisław. 2003. „Dezyderat trwałego rozwoju i warunki jego spełnienia. (Tezy)." W Filozoficzne i społeczne uwarunkowania zrównoważonego rozwoju, red. Artur Pawłowski, 14. Lublin: Komitet Ochrony Środowiska PAN.

Skowroński, Antoni. 2004. „Trudności i możliwości wdrażania koncepcji zrównoważonego rozwoju (Aspekty świadomościowe i praktyczne)." W Wokót biofilozofii Kazimierza Kloskowskiego. Wybrane zagadnienia, red. Maciej Bała, 195-214. Pelplin: Wydawnictwo Bernardinum.

Stacewicz, Janusz. 1998. „Cywilizacyjno-kulturowe uwarunkowania ekorozwoju." W Sterowanie ekorozwojem. Teoretyczne aspekty ekorozwoju, red. Bazyli Poskrobko, t. I, 106115. Białystok: Wydawnictwo Politechniki Białostockiej. 
Szaniawska, Daniela, i Andrzej R. Szaniawski. 1995. „Zrównoważony rozwój.” Ekonomia i Środowisko 2(7): 42-58.

Szponar, Adolf. 2003. Fizjografia urbanistyczna. Warszawa: Wydawnictwo Naukowe PWN.

Waloszczyk, Konrad. 2004. „Ku ekorozwojowi." W Zrównoważony rozwój. Zbiór opracowań, red. Anna Bogumił, 11-18. Warszawa: Wyższa Szkoła Menadżerska SIG.
Wikipedia. 2006. „Cywilizacja.” Accessed August 4, 2006. http://pl.wikipedia.org/wiki/ Cywilizacja.

Zięba, Stanisław. 1995. „Kryzys ekologiczny. Realność czy utopia." Człowiek i Przyroda 3: 5-26. Żukowska, Helena. 1996. Ekonomiczne aspekty ochrony środowiska naturalnego. (Na przyktadzie województwa lubelskiego). Lublin: Wydawnictwo Uniwersytetu Marii Curie-Skłodowskiej. 